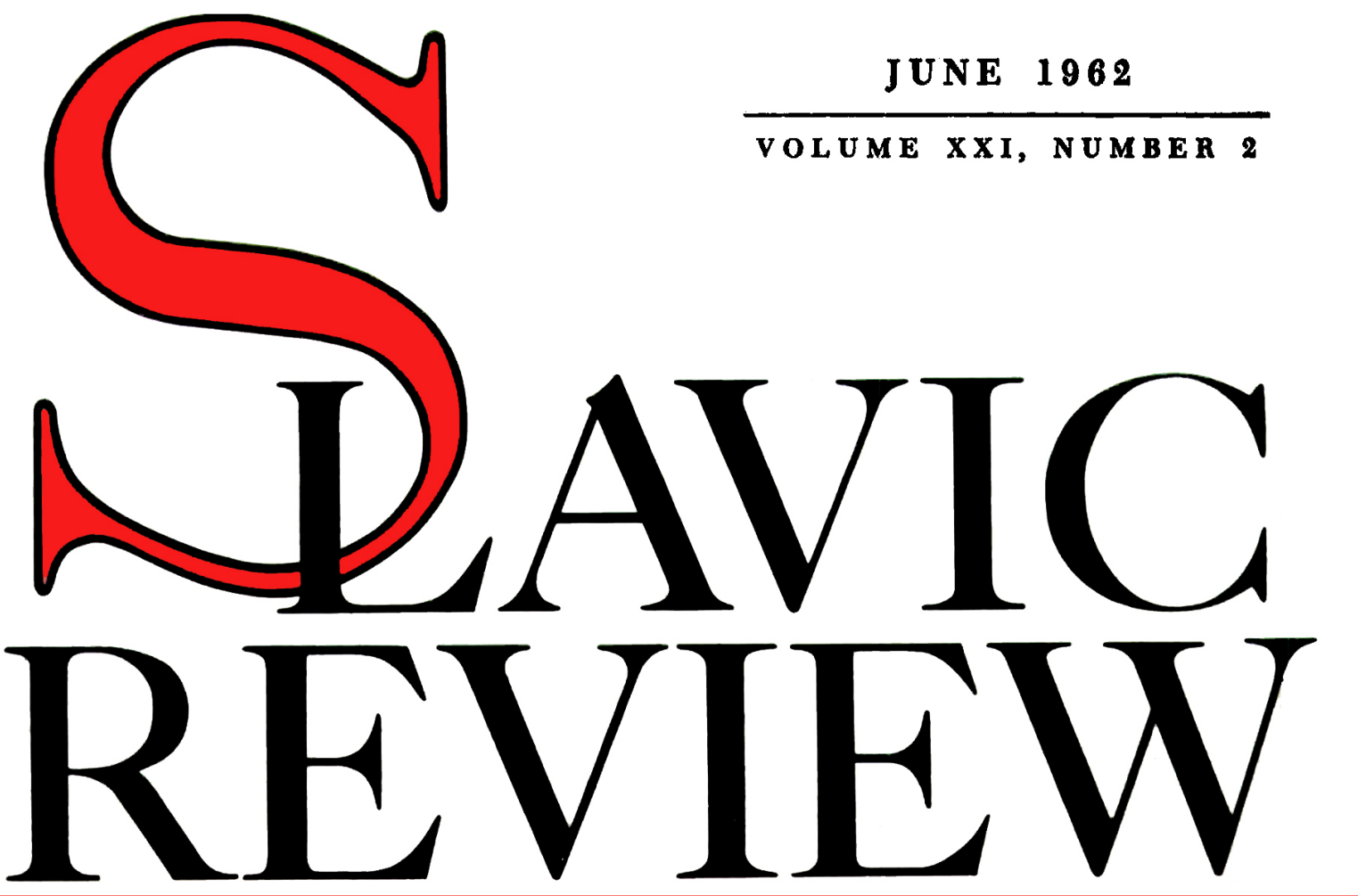

American Quarterly of Soviet and East European Studies

DIS C U S I O N

Gregory Grossman: The Structure and Organization of the

Soviet Economy - Comments by Henri Chambre and David Granick

A I T I C L E \&

Joseph Rothschild: The Military Background of Pilsudskis Coup dEtat

Richard Wortman: Koshelev, Samarin, and Cherkasky and the Fate of Liberal Slavophilim

John Mersereau, Jr.: Lermontov's Shtoss: Hoax or Literary Credo?

Edgar Anderson: The USSR Trades with Latvia: The Treaty of 1927

NOTESANDCOMMNT

Stevan K. Pavlowitch: Early Nineteenth-Century Serbia in the Eyes of British Travelers

Charles Jelavich: The Importance of the Leksikografski Zavod to the Scholar

REYIEW ARTICLE

Nikolay Andreyev: Recent Soviet Studies of Russian History and Culture Before 1462 
HONORARY EDITORS

Harold H. Fisher

GEROID T. ROBINSON
Oscar Halecki

ERNEST J. SimmoNS
WACLAW LEDNICKI

George VernadsKY

\section{EDITORIAL BOARD}

\section{WILliam B. EDgerTon Indiana University \\ Chauncy D. Harris University of Chicago \\ Marshall D. Shulman \\ Harvard University}

MANAGING EDITOR

Donald W. TREAdgold

University of Washington

\begin{abstract}
assistant editor: Gladys Greenwood
edtorial assistant: Leila Charbonneau
\end{abstract}

\author{
NEWS OF THE PROFESSION EDITOR \\ RALPH T. FISHER, JR. \\ University of Illinois
}

The Editors assume no responsibility for statements of fact or opinion made by contributors.

The SLAVIC REVIEW is published quarterly, in March, June, September, and December, by the American Association for the Advancement of Slavic Studies, Inc., and is sent to all Association members. Members also receive an annual American Bibliography of Slavic and East European Studies and a biannual Newsletter. Applications for membership are accepted by the Secretary of the Association, Professor Ralph T. Fisher, 337 Lincoln Hall, University of Illinois, Urbana, from individuals having professional engagement in the field. Nonmembers also may place subscriptions with Professor Fisher. Subscriptions, without membership, are $\$ 10.00$ a year, foreign and domestic postage included. Single numbers are $\$ 2.75$. Entered as second-class matter at the Post Office at Seattle, Washington.

Articles submitted and books for review, as well as all correspondence concerning editorial matters, should be addressed to Professor Donald W. Treadgold, 508 Thomson Hall, University of Washington, Seattle 5. Items for the "News of the Profession" section and all communications regarding membership and subscriptions should be sent to Professor Fisher in Urbana.

Copyright $\odot 1962$ by The American Association for the Advancement of Slavic Studies, Inc.

\section{EDITORIAL COMMITTEE}

FrEDERIGK C. BARGHOORN Yale University

ABRAM Bergson Harvard University

CYRIL E. BLACK Princeton University

DEMING BROWN University of Michigan

ROBERT F. BYRNES Indiana University

George B. Cressey Syracuse University

John S. CurTiss Duke University

Vicror ERLICH University of Washington

Merle FaINSOD Harvard University

Alexander Gerschenkron Harvard University

Alex INRELES Harvard University

Charles Jelavich Indiana University

Anatole G. Mazour Stanford University

PHILIP E. MOSELY Columbia University

OLIVER H. RADKEY University of Texas

HENRY L. ROBERTS Columbia University

ALFRED SENN University of Pennsylvania

Demitri B. Shimkin University of Illinois

Gleb STRuve University of California

S. HARRIson THOMSON University of Colorado

JULIAN TOWSTER University of California

RENe WeLLeK Yale University

Francis J. Whitrield University of California 


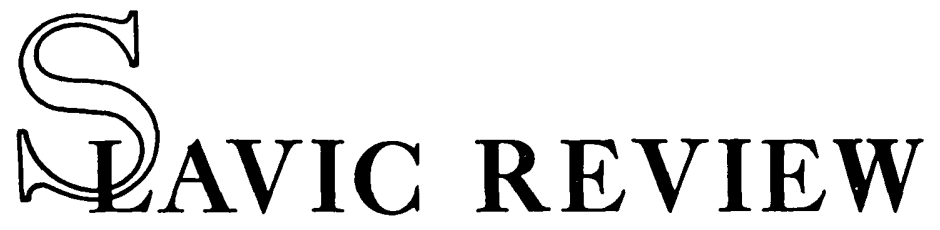

AMERICAN QUARTERLY OF SOVIET AND EAST EUROPEAN STUDIES

FORMERLY: THE AMERICAN SLAVIC AND EAST EUROPEAN REVIEW

MANAGING EDITOR

DONALD W. TREADGOLD

University of Washington

Seattle 5, Washington

\section{VOLUME XXI • 1962}

PUBLISHED AT THE UNIVERSTTY OF WASHINGTON FOR THE American Association for the Advancement of Slavic Studies 
Copyright $\mathbb{C} 1962$

by The American Association for

the Advancement of Slavic Studies, Inc.

PRINTED AT THE

UNIVERSITY OF WASHINGTON PRINTING PLANT

SEATTLE, WASHINGTON, U.S.A. 


\title{
CONTENTS OF VOLUME XXI
}

\section{DISCUSSION}

\author{
Number 1, March 1962
}

Georges Florovsky: The Problem of Old Russian Culture . . . . . 1

Nikolay Andreyev: Pagan and Christian Elements in Old Russia . . 16

James H. Billington: Images of Muscovy . . . . . . . . . . . 24

Georges Florovsky: Reply . . . . . . . . . . . . . . . . 35

\section{ARTICLES}

Zdenek V. David: The Influence of Jacob Boehme on Russian

Religious Thought . . . . . . . . . . . . . . . . . 43

Ante Kadic: The Croatian Renaissance . . . . . . . . . . . 65

Hans Heilbronner: The Russian Plague of 1878-79 . . . . . . . . . $\quad$. 89

NOTES AND COMMENT

Jan S. Prybyla: Private Enterprise in Poland Since 1957 . . . . . 113

REVIEW ARTICLE

Naum Jasny: The Soviet Statistical Yearbooks for 1955 Through 1960 . 121

Reviews . . . . . . . . . . . . . . . . . . . . . . 157

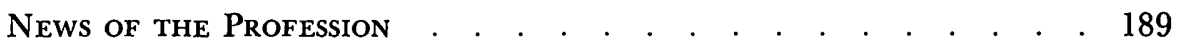

Books ReceIved . . . . . . . . . . . . . . . . . . . . . . . 199

DISCUSSION

Number 2, June 1962

Gregory Grossman: The Structure and Organization of the Soviet

Economy . . . . . . . . . . . . . . . . . . . . 203

Henri Chambre: Rationality in the Soviet Economy . . . . . . . $\quad 223$

David Granick: The More Answers, The More Questions . . . . . 229

Gregory Grossman: Reply . . . . . . . . . . . . . . . . 237

ARTICLES

Joseph Rothschild: The Military Background of Pilsudski's Coup

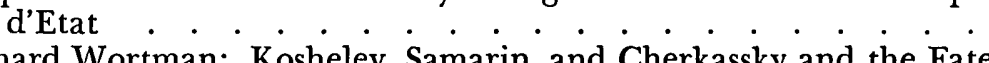

Richard Wortman: Koshelev, Samarin, and Cherkassky and the Fate of Liberal Slavophilism . . . . . . . . . . . . . . . 261

John Mersereau, Jr.: Lermontov's Shtoss: Hoax or Literary Credo? . 280

Edgar Anderson: The USSR Trades with Latvia: The Treaty of 1927 . 296

NOTES AND COMMENT

Stevan K. Pavlowitch: Early Nineteenth-Century Serbia in the Eyes of British Travelers. . . . . . . . . . . . . . . . . 322

Charles Jelavich: The Importance of the Leksikografski Zavod to the Scholar. . . . . . . . . . . . . . . . 330

REVIEW ARTICLE

Nikolay Andreyev: Recent Soviet Studies of Russian History and Culture Before 1462

Reviews . . . . . . . . . . . . . . . . . . . . . . 343

Letters . . . . . . . . . . . . . . . . . . . . . . 377

News of the Profession . . . . . . . . . . . . . . . . . . 378

Books ReGeIVED . . . . . . . . . . . . . . . . . . . 385 
Hugh McLean: The Development of Modern Russian Literature . . 389

Rufus W. Mathewson, Jr.: Russian Literature and the West . . . . 411

Gleb Struve: The Aesthetic Function in Russian Literature . . . . 418

Hugh McLean: Reply . . . . . . . . . . . . . . . . . 428

ARTICLES

Victor Erlich: The Dead Hand of the Future: The Predicament of Vladimir Mayakovsky

Valentine J. Boss: Kantemir and Rolli-Milton's Il Paradiso Perduto

Howard R. Swearer: Decentralization in Recent Soviet Administrative Practice

Philip E. Anderson: New Directions in Czechoslovak Agricultural Policy under Novotny .

NOTES AND COMMENT

Robert F. Byrnes: Reflections on American Training Programs on Russia (Comments by Cyril E. Black and George E. Taylor)

Alfred Erich Senn: The Formation of the Lithuanian Foreign Office, 1918-1921

REVIEW ARTICLES

John A. Armstrong: Recent Soviet Publications on World War II . . 508

Robert W. Campbell: The Growth of Soviet Output . . . . . . 520

Reviews . . . . . . . . . . . . . . . . . . . . . . 527

LETTERS . . . . . . . . . . . . . . . . . . . . . . 577

News of the Profession .. . . . . . . . . . . . . . . . . . . 583

BOOKS RECEIVED . . . . . . . . . . . . . . . . . . . 592

DISCUSSION Number 4, December 1962

Wayne S. Vucinich: The Nature of Balkan Society under Ottoman

Stanford J. Shaw: The Aims and Achievements of Ottoman Rule 597

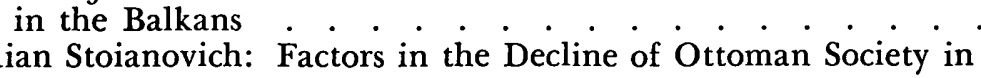
the Balkans . . . . . . . . . . . . . . . . . . . 623

Wayne S. Vucinich: Reply. . . . . . . . . . . . . . . . 633

\section{ARTICLES}

Oswald P. Backus III: The Problem of Feudalism in Lithuania, $1506-1548$

Alfred Levin: The Russian Voter in the Elections to the Third Duma . 660

Karl A. Wittfogel: Agrarian Problems and the Moscow-Peking Axis . 678

NOTES AND COMMENT

Anthony Palecek: Antonin Svehla: Czech Peasant Statesman . . . 699

Temira Pachmuss: Soviet Studies of Dostoevsky, 1935-1956 . . . . 709

REVIEW ARTICLE

George S. N. Luckyj: Shevchenko Studies One Century after the Poet's Death

Reviews . . . . . . . . . . . . . . . . . . . . . 736

LETTERS . . . . . . . . . . . . . . . . . . . . . . . 789

News of the Profession . . . . . . . . . . . . . . . . . . 790

BOOKS RECEIVED . . . . . . . . . . . . . . . . . . . . . 799

INDEX TO VolUME XXI . . . . . . . . . . . . . . . . . 803 